\title{
FOREIGN TRADE, EDUCATION, AND INNOVATIVE PERFORMANCE: A MULTILEVEL ANALYSIS
}

\author{
Ahmet Faruk Aysan*, Luis Carlos Castillo-Téllez**, Dilek Demirbaş***, and \\ Mustafa Disli**** \\ * College of Islamic Studies, Hamad Bin Khalifa University, Qatar. Email: aaysan@hbku.edu.qa \\ ** Faculty of Economics, Istanbul University, Istanbul, Turkey. Email: luisc.castillot@utadeo.edu.co \\ *** Faculty of Economics, Istanbul University, Istanbul, Turkey.Email: dilek.demirbas@istanbul.edu.tr \\ **** College of Islamic Studies, Hamad Bin Khalifa University, Qatar. Email: mdisli@hbku.edu.qa
}

\begin{abstract}
This study analyses the innovative performance of 5,273 companies across 64 different economic sectors and 32 different regions in Colombia. We assess the effects of education and open economy variables on the innovative performance of firms by analyzing firm, sectoral, and regional level determinants. The study takes the multilevel approach of the innovation process considering the structure and behavior of innovation systems in developing countries. We furthermore focus on technology transfer from foreign trade and the role of education in the process of innovation. We find that education and open economy variables have a significant relationship with innovation performance at the firm and regional levels. We finally conclude that Colombia has a fragmented innovation system with a weak institutional structure, and low interaction between policymakers, industry, universities, research centers.
\end{abstract}

Keywords: Multilevel approach; Innovative performance; Open economy variables; Innovation systems; Multilevel regression models; Development.

JEL Classifications: O31; O32.

Article history:

Received : December 21, 2020

Revised : : February 22, 2021

Accepted : June 03, 2021

Available Online: September 30, 2021

https://doi.org/10.21098/bemp.v24i3.1543 


\section{INTRODUCTION}

What are the roles of education and Open Economy Variables (OEV) in the innovative performance of Colombian manufacturing firms? In support of the Innovation System (IS) theory, it has been found that both education and foreign trade are crucial in the development of new knowledge, technology transfer, and knowledge spillovers (Keller, 2010; Lundvall et al., 2009; Srholec, 2011, 2015). Recent contributions to the literature have not only shown that the educational institutions in Colombia should be capable of transferring knowledge to the industry (Vélez-Rolón et al., 2020), but also confirmed that imports are positively related with science, technology, and innovation activities (Guevara-Rosero, 2020)

Seminal studies on the IS theory were conducted by Lundvall (1985) and Freeman (1982). While Lundvall (1985) analyzed innovation at the microlevel, whereby the user-producer interactions shaped the development of new technologies and products, Freeman (1982), from a macro-perspective, underlines the relation between innovation and international trade, emphasizing the importance of building a technological infrastructure at the national level. From this macro perspective, company innovation is at the center of analysis but is seen in the larger context of the network of institutions, whose interactions enable the diffusion of new technologies. Firms are exposed to a context in which international trade (Laurin and St-Pierre, 2011) and capital mobility (Keller, 2010) become a bridge of technology transfer between the global knowledge networks and the IS. In addition, universities play a significant role in the formation of human capital and scientific research. These education institutions provide skilled labor, while also being a source of specific knowledge transfer for different industries (OECD, 2012; UNCTAD, 2014). In Latin America, however, cross-country analysis of innovation performance at the firm level has encountered two main constraints. First, the enforcement of new legislations that control the access to microdata files in different countries (Guillard and Salazar, 2017). Second, differences in data collection procedures among Latin American countries often prevent meaningful comparisons across countries (Guillard and Salazar, 2017). So far, studies on Colombia that relate innovation systems with multilevel models have been limited to two levels, viz., firm and regional levels (Barrios-Aguirre, 2013; Zuluaga Jiménez et al., 2012). This study adds to the literature by considering an additional dimension of sectoral innovation, which allows us to perform a threelevel analysis (i.e., firm, sector, and region). Accordingly, the main objective of this research is to determine whether OEV and education variables have a significant relationship with the innovative performance of Colombian manufacturing firms considering a multilevel analysis.

This paper presents a multilevel quantitative technique to analyze the innovative performance of the manufacturing industry in Colombia based on the theory of regional and sectoral IS. In particular, the microdata from the Technological Development and Innovation Survey (EDIT) 2007-2008 and merging different datasets mainly provided by the National Department of Statistics (DANE) allows us to build a database that has a hierarchical structure in which companies can be classified according to their economic activities (or sector) and regions in which those firms have their headquarters. By doing so, this study examines 5273 firms operating in 64 different economic sectors and 32 regions in Colombia. 
The major conclusion of this study is that, at the firm level, foreign capital harms innovation performance unless firms allocate the foreign capital inflows to R\&D activities. At the sectoral level, however, we find weak statistical evidence regarding the influence of OEV variables on innovation performance. At the regional level, foreign trade has a positive influence on innovation performance due to technology transfer. In addition, tertiary education plays a significant role in the development of innovation at the firm and regional levels, hence, indicating the importance of strengthening the university-industry collaboration in the Colombian innovation system.

This paper is organized as follows. Section II introduces the multilevel regression model and the variables. In Section III, we present the data and it is followed by Section IV, estimation of the model, and the results. Then, in the final section (Section V), we conclude the paper and make policy implications.

\section{METHODOLOGY}

\section{A. From Multilevel Analysis to Multilevel Modeling}

In general, individuals interact in a social environment to which they belong. As a result of this, individuals are influenced by this social environment and vice versa (Gupta et al., 2007). In other words, individuals are nested within social groups at different levels creating a hierarchical interconnected structure. A commonality among multilevel regression models ${ }^{1}$ is the hierarchical structure of data with the dependent variable at the lowest level and the independent variables at highest levels (Gelman and Hill, 2006; Hox et al., 2017). Multilevel Poisson regression analyses have been used by different disciplines that study embedded data of multilevel phenomena. The reliability of the model depends on the quality of the data as well as the adopted methodology in the estimation process. As the innovation process happens in the firm, sectors, and regions, there are some unobserved conditions by the model. Heterogeneity or variations across individuals, such as firms, sectors, and regions, are unobserved by the model (Hox et al., 2017; Wooldridge, 2002). However, if we use multilevel models with random parameters and mixed effects the unobserved individual-specific heterogeneity is assumed to be unrelated to the explanatory-variable vector. Following Gupta et al. (2007), in the field of innovation, the hierarchical structure is visible as firms appear to be the individuals that are clustered in sectors, and these sectors are allocated within regions.

Considering the challenges involved in explaining the causality between the variables of interest and innovation performance, this study proposes the following hypothesis:

H1: Innovative performance is significantly related to open economy variables even though the nature of the relation varies at the regional, sectoral, and firm levels in developing economies.

${ }^{1}$ Random coefficient models, variance component models, hierarchical linear models, mixed effect models, and so on (Hox et al., 2017). 
According to Fagerberg et al. (2009), education is one of the main components of the social capabilities in IS. Thus, we hypothesize that:

H2: From the multilevel dimensional perspective, higher education, such as a doctorate, master, undergraduate, or associate degree, is expected to contribute to the firm's innovation performance.

\section{B. Determinants of Innovation from a Multilevel Dimension}

From the multilevel dimensional perspective, each of the three levels will encompass a set of determinants that are linked to the main components of the Regional Innovation Systems (RIS) (Padilla-Pérez et al., 2009), the building blocks of Sectoral Innovation Systems (SIS) (Joseph, 2009; Malerba, 2002; Srholec, 2011), and the firms' characteristics (Hadhri et al., 2016).

\section{B.1. Regional Level Determinants}

The regional level determinants encompass characteristics outside the firm that can influence innovation performance. Within the context of developing countries, the determinants tend to change due to the existence of heterogeneity across countries and regions (Srholec, 2015). According to the characteristics of the Colombian IS, the following determinants will be tested within the econometric model.

Following the literature, imports and exports bring along technological and knowledge spillovers that have a positive effect on productivity and innovative performance, nevertheless, the relationship between international trade and innovation in developing countries can bring positive or negative results (Bernard and Bradford Jensen, 1999; Hadhri et al., 2016; Keller, 2010; Lefebvre and Lefebvre, 2002; Padilla-Pérez et al., 2009; Vogel and Wagner, 2010; Juhro et al., 2020). Coverage on higher education and human capital formation is crucial in the process of innovation (Lundvall, 2015; Juhro et al., 2020; Vélez-Rolón et al., 2020). In developing economies, however, the lack of basic and advanced educational systems and the failure of governments to allocate resources for research and higher education hinder innovation performance (Kuhlmann and OrdóñezMatamoros, 2017). Technological unemployment happens when cutting-edge technology disrupts labor markets and creates jobs with high-income cognitive tasks and displace low-income manual occupations and routine tasks (Frey and Osborne, 2017). Evidence from seven Latin American countries, however, shows that investment in science and technology does not affect the unemployment rate (Aguilera and Ramos-Barrera, 2016). The distance to the capital city and other main cities, geographical proximities to production, skilled labor, high wages, and institutions make interactions, flows of information, and knowledge more effective (Ascani et al., 2012; Feldman and Audretsch, 1999)

\section{B.2. Sectoral Level Determinants}

The interactions between the building blocks within the sectoral IS and the main components of the regional IS play a significant role in the exchange of information, knowledge, and technology, as such innovation within sectors takes place (Joseph, 
2009). At this level, the following determinants were tested in the econometric model. Similar to the regional level, international trade (export rate, trade openness index, foreign capital) brings knowledge and technology spillovers that influence innovative performance. Maleçrba (2005) states that firms are embedded in heterogeneous sectors in which they use different technologies, networks, and institutions. Furthermore, trade may bring different effects that could change according to industry characteristics and composition (ICTSD, 2016). Regarding the concentration of knowledge, Pavitt's Taxonomy distinguishes sectoral innovation patterns considering four types of innovative-firms: science-based, specialized-suppliers, supplier-dominated, and resource-intensive (Bogliacino and Pianta, 2016). On the other hand, Gera and Masse (1996) argue that some industries demand higher R\&D investment than others industries, identifying three knowledge intensity groups: high, medium, and low-knowledge industries. The concentration of innovation takes place on economies of scale, specialized suppliers, and science-based industries, where innovation activities are more intense than industries that are dominated by suppliers (Urraca-Ruiz, 2000). A recent study reveals how digital technologies are redesigning the concentration of innovation activities (Paunov et al., 2019).

\section{B.3. Firm Level Determinants}

Innovation performance depends on the characteristics of the firm and the synergy with the regional and sectoral innovation system. Hadhri et al. (2016) found that the determinants of innovative performance can change according to the context in which firms are exposed. The following determinants found in the literature are included in our regressions. The size of companies has a positive relationship with R\&D investment (Schumpeter, 1934, 1943). Cohen and Klepper (1996) and Cohen and Levin (1989) claim that larger companies have access to different external technological resources and a higher budget to invest in R\&D. Next to size, Hadhri et al. (2016) suggest the inclusion of control variables, such as education, networks, human capital, and others. According to Powell and Grodal (2006), networks foster the trade of knowledge. Nowadays, technology and information flows are important to acquire the knowledge needed to develop and commercialize new products. For this reason, inter-organizational partnerships are important in the development of networks (Ardito et al., 2015). Networks in the era of digital globalization can furthermore generate a suitable environment for innovation performance (Manyika et al., 2018). Evidence also suggests that $\boldsymbol{R} \mathcal{E} \boldsymbol{D}$ expenditure generates a positive effect on innovation and productivity (Baumann and Kritikos, 2016; MacGregor-Pelikánová, 2019; Prodan et al., 2005). In developing countries, however, the resources allocated to R\&D are relatively low (Morero, 2017). Hence, the government should create public policies aimed to increase firms' capabilities to absorb foreign knowledge to improve innovation performance and development (Morero, 2017). Human capital is crucial in the innovative behavior of firms. Romijn and Albaladejo (2002) mentioned the need to have trained and skilled people in areas such as engineering, science, and others. Firms in emerging economies, however, do not have access to a labor force with technological-oriented skills that are needed in the development of high-quality goods and services (Morero, 2017). 
In a low-resource context, where there is less collaboration between universities and industry, firms will also have to make more effort to build up their human capital (Albats et al., 2020; Marotta et al., 2007). Finally, the role played by Foreign Direct Investment (FDI) in innovative performance is significant. The innovation literature (De Marchi and Grandinetti, 2017; Keller, 2010; Morero, 2017; PadillaPérez et al., 2009) has mentioned how emerging economies have created policies to attract FDI to promote growth and development, and to facilitate technology transfer. Nevertheless, in some countries, these policies are designed to boost sectors related to commodity extraction. For example, the OECD (2014) indicates that a substantial amount of FDI in Colombia has been captured by the mining sector rather than technologically oriented sectors.

\section{DATA AND EMPIRICAL METHODOLOGY}

\section{A. Data}

The data was taken from different official sources, such as DANE, National Department of Planning (DNP), Ministry of Education, Ministry of Commerce, Industry and Tourism; Directorate of Taxes and National Customs (DIAN), and Procolombia. The latest publicly available version of this survey is the EDIT (20072008). In recent years, however, the Colombian government has issued certain laws that restrict access to these databases.

The first- or firm-level data comprises 5273 firms obtained from EDIT (20072008). The second- or industry-level data contains 64 groups of economic activities identified according to the International Standard Industrial Classification of All Economic Activities, Rev.3 (ISIC Rev3). The third or regional level data include variables of the 32 departments of regions from Colombia.

To build the database, we develop the following measurements. The dependent variable is the total count of innovations. This variable is the summation of all nine types of innovations (see Table 1) that every firm was able to achieve during the period of the survey. This categorization can be found in the EDIT 2007-2008 survey.

\section{Table 1.}

\section{Types of Innovation}

This table reports the types of innovation based on the Technological Development and Innovation Survey (EDIT) 2007-2008.

1. New goods or services for the company

2. New goods or services for the national market

3. New goods or services for the international market

4. Goods or services significantly improved for the company.

5. Goods or services significantly improved for the national market.

6. Goods or services significantly improved for the international market.

7. New or significantly improved methods of production, distribution, delivery, or logistics systems, implemented in the company.

8. New organizational methods are implemented in the internal functioning, in the knowledge management system, in the organization of the workplace, or the management of external relations of the company.

9. New or significantly improved marketing techniques (channels for promotion and sale, or significant changes in packaging or product design), implemented in the company to expand or maintain its market. (Changes that affect the functionalities of the product are excluded). 
The EDIT 2007-2008 survey classifies three types of innovation, namely radical, incremental, and strategic, ${ }^{2}$ and measures the innovation performance by counting the accumulation of innovations within two years. The dependent variable used in this study is the total count of innovations, which is the summation of the three above-mentioned types. Table 2 gives the summary statistics of the dependent variable.

Table 2.

\section{Descriptive Statistics of the Total Count of Innovations}

This table reports the descriptive statistics of the total count of innovation based on the Technological Development and Innovation Survey (EDIT) 2007-2008.

\begin{tabular}{lc}
\hline Variable & Total Count of Innovations \\
\hline Average & 8.787 \\
Variance & $4,520.210$ \\
Standard deviation & 67.232 \\
Max Value & 2,560 \\
Min Value & 0,000 \\
Negative values & 0,000 \\
Positive Values & 2,127 \\
Zero values & 3,146 \\
Observations & 5,273 \\
\hline
\end{tabular}

Source: Calculations based on EDIT 2007-2008

According to the EDIT 2007-2008 survey, 40\% of the firms reported, on average, 46,338 innovations, while $60 \%$ of the firms did not innovate at all. Table 2 shows that the total count of innovation is a discrete variable that contains non-negative values, with a distribution that describes a Poisson process $^{3}$ (see Figure 1).

The independent variables at the sectoral and regional level had the following treatment. The continuous variables between 2007 and 2008 were averaged and standardized (see Table 3). Most of the independent variables at the firm, sector, and regional levels are continuous (see Table A.1, for summary statistics). However, some variables are discrete, which in this case we included dummy variables in the model.

\section{B. Models of Count Data}

These regression models are for non-negative integer or counts, for instance, the dependent variable as count of innovations takes values $y=0,1,2 \ldots$ without upper explicit limit (Winkelmann, 2008). For this type of data, the Poisson Regression Model (PRM) is the appropriate one. This model assumes, in this case, that innovation is an event and behaves as a Poisson process, which is a stochastic

2 DANE defines radical innovations as new goods or services; incremental innovations as goods and services that are significantly improved and strategic innovations are new organizational methods applied to management and production processes.

3 Winkelmann (2008) describes the Poisson process as a special event count in which a stochastic process is carried out. This stochastic process is the accumulation of random variables (in a probability space) at a certain period. 
Figure 1.

Histogram of the Total Count of Innovations

This figure reports the total counts of innovation based on the Technological Development and Innovation Survey (EDIT) 2007-2008.

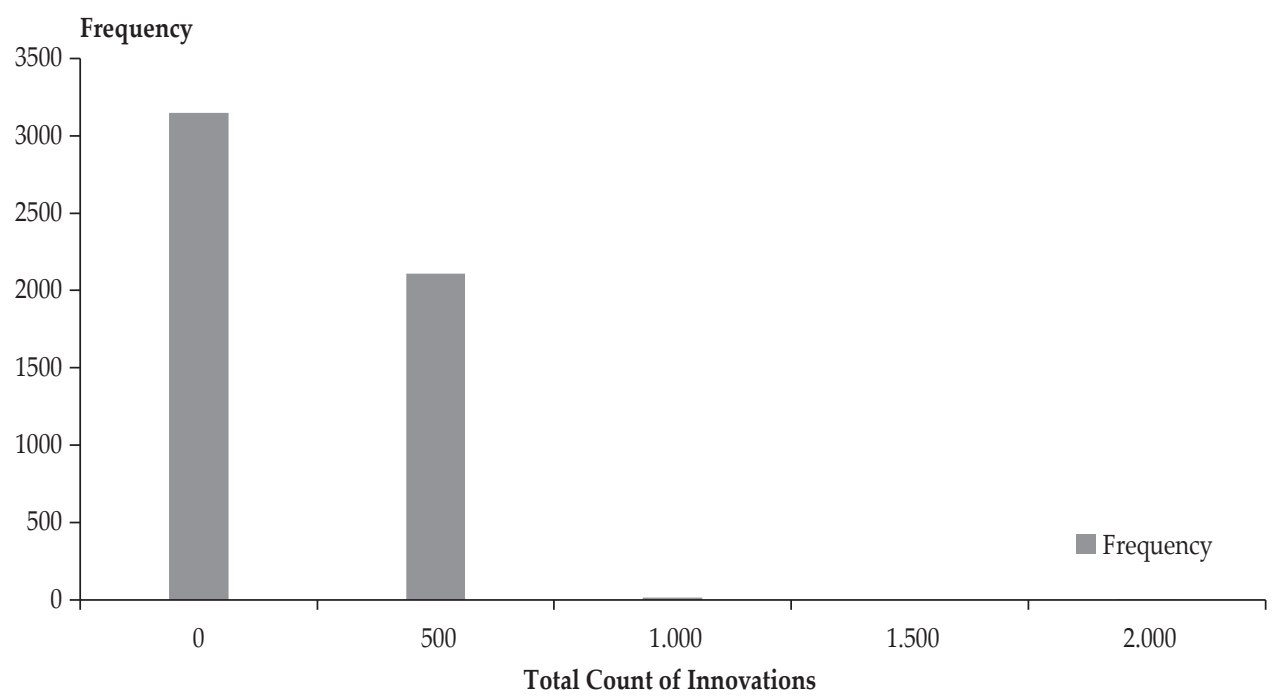

Table 3.

List of Independent Variables by Level

This table reports the description of innovation for firms (level 1) along with their sector (level 2) and regional headquarters (level 3).

\begin{tabular}{|c|c|c|}
\hline Level & Variables & Description \\
\hline \multirow[t]{8}{*}{1} & $\begin{array}{l}\text { Firms with foreign } \\
\text { capital. }\end{array}$ & $\begin{array}{l}\text { Companies with more than } 25 \% \text { of foreign capital will be considered a } \\
\text { foreign company, this variable is binary where } 1 \text { are foreign companies } \\
\text { and } 0 \text { otherwise. Source: EDIT 2007-2008. (Dummy) }\end{array}$ \\
\hline & Size. & $\begin{array}{l}\text { According to the number of employees, the average is taken between } \\
\text { 2007-2008. Source: EDIT 2007-2008. (Standardized) }\end{array}$ \\
\hline & $\begin{array}{l}\text { Percentage of } \\
\text { national private } \\
\text { capital invested in } \\
\text { R\&D. }\end{array}$ & $\begin{array}{l}\text { The total of own, foreign, and public resources divided by the total } \\
\text { of private resources invested in R\&D. Source: EDIT 2007-2008. } \\
\text { (Standardized) }\end{array}$ \\
\hline & $\begin{array}{l}\text { Percentage of foreign } \\
\text { private capital } \\
\text { invested in R\&D. }\end{array}$ & $\begin{array}{l}\text { The companies that within their total capital have a percentage of private } \\
\text { foreign capital invested in R\&D. Source: EDIT 2007-2008. (Standardized) }\end{array}$ \\
\hline & Internal Networks. & $\begin{array}{l}\text { The companies' departments that participate in innovations } \\
\text { developments, internal networks that the firm used over the total of } \\
\text { networks (Int + Exter). Source: EDIT 2007-2008. (Standardized) }\end{array}$ \\
\hline & External Networks. & $\begin{array}{l}\text { External networks (clients, suppliers, universities, chambers of } \\
\text { commerce, etc.) that the firm uses over the total of Int + Exter networks. } \\
\text { Source: EDIT 2007-2008. (Standardized) }\end{array}$ \\
\hline & Partner cooperation. & $\begin{array}{l}\text { If the company had partner cooperation or not. Source: EDIT 2007-2008. } \\
\text { (Dummy) }\end{array}$ \\
\hline & $\begin{array}{l}\text { Level of education: } \\
\text { Bachelor, Master, } \\
\text { and Ph.D. }\end{array}$ & $\begin{array}{l}\text { Employees with Ph.D., Master, and Bachelor degrees are divided by the } \\
\text { total employees. Source: EDIT 2007-2008. (Standardized) }\end{array}$ \\
\hline
\end{tabular}


Table 3.

\section{List of Independent Variables by Level (Continued)}

\begin{tabular}{|c|c|c|}
\hline \multirow[t]{6}{*}{ Level } & Variables & Description \\
\hline & $\begin{array}{l}\text { Level of education: } \\
\text { associate degree. }\end{array}$ & $\begin{array}{c}\text { Employees with associate degrees are divided by total employees. } \\
\text { Source: EDIT 2007-2008. (Standardized) }\end{array}$ \\
\hline & $\begin{array}{l}\text { Level of education: } \\
\text { Bachelor, Master, } \\
\text { and Ph.D. involve in } \\
\text { R\&D. }\end{array}$ & $\begin{array}{l}\text { Employees with Ph.D., Master, and Bachelor degree involve with R\&D } \\
\text { divided by the total employees. Source: EDIT 2007-2008. (Standardized) }\end{array}$ \\
\hline & $\begin{array}{l}\text { Level of education: } \\
\text { associate degree } \\
\text { involves in R\&D. }\end{array}$ & $\begin{array}{l}\text { Employees with associate degrees involve in R\&D divided by the total } \\
\text { employees. Source: EDIT 2007-2008. (Standardized) }\end{array}$ \\
\hline & $\begin{array}{l}\text { Intellectual property } \\
\text { and patents. }\end{array}$ & $\begin{array}{l}\text { Summation of all types of intellectual property and patents that the } \\
\text { company reported. Source: EDIT 2007-2008. (Standardized) }\end{array}$ \\
\hline & $\begin{array}{l}\text { Foreign R\&D } \\
\text { Financing. }\end{array}$ & $\begin{array}{l}\text { The total of own, foreign, and public resources divided by the total } \\
\text { of foreign resources invested in R\&D. Source: EDIT 2007-2008. } \\
\text { (Standardized) }\end{array}$ \\
\hline \multirow[t]{5}{*}{2} & $\begin{array}{l}\text { Knowledge intensity: } \\
\text { High. }\end{array}$ & $\begin{array}{c}\text { According to the Gera and Masse classification (1996). Source: DANE } \\
\text { Methodology Indicators of Industrial Competitiveness by Intensity of } \\
\text { Knowledge. (Dummy) }\end{array}$ \\
\hline & $\begin{array}{l}\text { The intensity of } \\
\text { knowledge: Low. }\end{array}$ & $\begin{array}{c}\text { According to the Gera and Masse classification (1996). Source: DANE } \\
\text { Methodology Indicators of Industrial Competitiveness by Intensity of } \\
\text { Knowledge. (Dummy) }\end{array}$ \\
\hline & Intensity of R\&D. & $\begin{array}{l}\text { Number of large companies that invested in R\&D is divided by the } \\
\text { number of companies that invest in R\&D in the sector. Source: EDIT } \\
\text { 2007-2008. (Standardized) }\end{array}$ \\
\hline & $\begin{array}{l}\text { Sectors with foreign } \\
\text { capital. }\end{array}$ & $\begin{array}{l}\text { The number of companies with foreign capital is divided by the number } \\
\text { of companies in the sector. Source: EDIT 2007-2008. (Standardized) }\end{array}$ \\
\hline & $\begin{array}{l}\text { Commercial Opening } \\
\text { Index of the sector. }\end{array}$ & $\begin{array}{l}\text { It is the average of imports plus exports as a share of GDP for the years } \\
\text { 2007-2008. Source: DANE, Competitiveness indicators, foreign trade. } \\
\text { (Standardized) }\end{array}$ \\
\hline \multirow[t]{6}{*}{3} & $\begin{array}{l}\text { Unemployment rate } \\
\text { by department }\end{array}$ & $\begin{array}{c}\text { Average unemployment rate by department (2007-2008) Source: DANE, } \\
\text { labor market. (Standardized) }\end{array}$ \\
\hline & $\begin{array}{l}\text { Coverage in higher } \\
\text { education. }\end{array}$ & $\begin{array}{l}\text { Average of the higher education coverage rate in } 2007 \text { and 2008. Source: } \\
\text { Ministry of Education, SNIES (National Information System of Higher } \\
\text { Education) Database. (Standardized) }\end{array}$ \\
\hline & $\begin{array}{l}\text { Commercial opening } \\
\text { index of the region. }\end{array}$ & $\begin{array}{l}\text { It is the ratio between the average of imports plus exports and the GDP } \\
\text { for the years } 2007 \text { and 2008. Source: DANE, foreign trade. (Standardized) }\end{array}$ \\
\hline & $\begin{array}{l}\text { National investment } \\
\text { by region in R\&D }\end{array}$ & $\begin{array}{l}\text { Average of the R\&D Investment by the department for the years 2007- } \\
\text { 2008. Source: OCYT. (Standardized) }\end{array}$ \\
\hline & $\begin{array}{l}\text { Distance to the } \\
\text { Capital. }\end{array}$ & $\begin{array}{c}\text { Kilometers away from the capital of each department of the region. } \\
\text { Source: Google Earth. (Standardized) }\end{array}$ \\
\hline & Research groups & $\begin{array}{l}\text { Average of active research groups between 2007-2008. Source: } \\
\text { Observatory of Science and Technology OCYT. (Standardized) }\end{array}$ \\
\hline
\end{tabular}

process that calculates the probability of the occurrence of an event in a certain period (Winkelmann, 2008).

As we see, in Table 2, the variance is larger than the mean and the dependent variable has 3146 zero values. These excessive zeros imply the sample violates the equi-dispersion assumption in the PRM, in which the mean is equal to the 
variance. To solve this problem, the Zero Inflated Poisson Model (ZIP Model) or Zero Inflated Negative Binomial Model (ZINB Model), which is an extension of PRM has been used in the literature (Lee et al., 2006; Winkelmann, 2008). This number of zeros in the survey are common in developing countries. According to RICYT (2018), in countries like Argentina, Brazil, and Chile, less than $40 \%$ of the firms innovate. The Colombian case is not very much different from that, as approximately $60 \%$ of the companies did not innovate, according to the EDIT 2007-2008 survey.

\section{Applying the Multi-level Zero-inflated Poisson ZIP Model}

Following the literature (Hox et al., 2017; Hur et al., 2002; Lambert, 1992; Lee et al., 2006; Long, 1997; Wang et al., 2011), this paper uses multilevel models with mixedeffects that involve count data, since this is the nature of the dependent variable. To run a multi-level model with a high number of zeros, Long (1997) suggests to classified these zeros into two groups. First, we have structural zeros with a $\pi_{i}$ probability, which represents companies that always have zero innovation counts, given that these companies structurally do not comply with the technological capabilities to innovate. Second, circumstantial zeros with $\left(1-\pi_{i}\right)$ probability may occur because even though companies comply with the technological capabilities to develop innovations, they do not achieve their innovation goals at the end of the period, or because innovation was still underway at the time of the survey.

Following Lambert (1992), the ZIP technique can run a Poisson and a logit model simultaneously. The Poisson model allows us to find not only the circumstantial zeros but also the arrival rate or innovation count, while the logit model estimates the probability when firms do not innovate. Traditionally, this type of model can be generated from an approximation of a generalized linear mixed model by the maximum likelihood technique (see Wang et al., 2011; Hur et al., 2002; Lee et al., 2006).

In multilevel models, the variables are expressed in a linear system of equations as below ${ }^{4}$.

$$
\begin{aligned}
& y_{i j k}=\beta_{0 j k}+\alpha_{1} x_{1 j k}+\beta_{1} Z_{1 j k}+e_{i j k} \\
& \beta_{0 j k}=\gamma_{00 k}+\gamma_{01} W_{1 j k}+u_{0 j k} \\
& \gamma_{00 k}=\eta_{000}+\eta_{011} G_{1 k}+v_{00 k}
\end{aligned}
$$

where $y_{i j k}$ represents the count of innovation for firm $i$ (level 1) operating in sector $j$ (level 2) and headquartered in region $k$ (level 3). $Z_{1 j k}$ is a vector of variables at the firm level, $\beta_{0 j k}$ represents the intercept in the first level that changes according to the sector's determinants $W_{1 j k^{\prime}}$ and $\gamma_{00 k}$ is the intercept in the second level, which varies according to the regional determinants $G_{1 k}$. Integrating Equations (1) to (3) gives us:

\footnotetext{
${ }_{4}$ Usually, multilevel models have cross-level interaction effects. To have a deeper understanding of these effects, we refer to Gelman and Hill (2007) and Hox et al. (2017).
} 


$$
y_{i j k}=\eta_{00}+\eta_{01} G_{1 k}+\gamma_{01} W_{1 j k}+\alpha_{1} x_{1 j k}+\beta_{1} Z+u_{0 j k}+v_{00 k}+e_{i j k}
$$

This model is similar to an ordinary linear regression model with fixed effects $\alpha_{1}, \gamma_{00 k^{\prime}} \gamma_{01}, \eta_{00^{\prime}} \eta_{01}$ and random coefficients $u_{0 j k^{\prime}} v_{00 k^{\prime}} e_{i j k}$.

The maximum likelihood (ML) method is commonly used to estimate multilevel models. The ML technique is generally robust and gives estimates that are asymptotically efficient and consistent (Hox et al., 2017). The advantages and limitations when using multilevel models are generally associated with the quality and the structure of the data. As the innovation process happens at different levels, there are some unobserved conditions by the model which is also known as unobserved heterogeneity. The differences between firms, sectors, and regions are unknown by the model. Multilevel models with random parameters and mixed effects assume, however, that the unobserved individual-specific heterogeneity is unrelated to the explanatory-variable vector. By considering the hierarchical structure of the data, multilevel models prevent type I errors and aggregation biases, which consist of making statistical inferences at the individual level from aggregate data (Wang et al., 2011).

Table 4.

\section{Results of the Multi-level Zero Inflated Poisson ZIP Model}

This table reports the results using the multi-level Zero Inflated Poisson ZIP model with and without Open Economy Variables (OEV) for the full sample. Dependent Variable is total count of innovation based on the Technological Development and Innovation Survey (EDIT) 2007-2008. The ISIC level belongs to the sector level and CD to the regional level. Standard errors robust to heteroscedasticity are in the parentheses. ${ }^{*}{ }^{* *}$, and ${ }^{* * *}$ denote statistical significance at the $10 \%, 5 \%$, and $1 \%$ levels, respectively.

\begin{tabular}{|c|c|c|c|c|c|c|}
\hline Variables & $\begin{array}{c}\text { Poisson } \\
\text { without } \\
\text { OEV }\end{array}$ & ISIC & CD & $\begin{array}{c}\text { Poisson } \\
\text { with } \\
\text { OEV }\end{array}$ & ISIC & CD \\
\hline Observations & 5,273 & 5,273 & 5,273 & 5,273 & 5,273 & 5,273 \\
\hline Number of Groups & & 64 & 32 & & 64 & 32 \\
\hline Constant & $\begin{array}{c}2.292^{* * *} \\
(0.075)\end{array}$ & $\begin{array}{c}0.991^{* * *} \\
(0.113)\end{array}$ & $\begin{array}{c}1.024^{* * *} \\
(0.037)\end{array}$ & $\begin{array}{c}2.295^{* * *} \\
(0.105)\end{array}$ & $\begin{array}{c}0.980^{* * *} \\
(0.115)\end{array}$ & $\begin{array}{l}1.023^{* * *} \\
(0.037)\end{array}$ \\
\hline Firms with foreign capital & & & & $\begin{array}{c}-0.180^{* * *} \\
(0.026)\end{array}$ & & \\
\hline Foreign R\&D Financing & & & & $\begin{array}{l}0.028^{* * *} \\
(0.002)\end{array}$ & & \\
\hline $\begin{array}{l}\text { Percentage of foreign private } \\
\text { capital invested in R\&D }\end{array}$ & & & & $\begin{array}{c}0.0134^{* * *} \\
(0.000)\end{array}$ & & \\
\hline OSize & $\begin{array}{c}0.104^{* * *} \\
(0.002)\end{array}$ & & & $\begin{array}{c}0.112^{* * *} \\
(0.002)\end{array}$ & & \\
\hline $\begin{array}{l}\text { Percentage of national private } \\
\text { capital invested in R\&D }\end{array}$ & $\begin{array}{c}-0.087^{* * *} \\
(0.004)\end{array}$ & & & $\begin{array}{l}0.151^{* * *} \\
(0.020)\end{array}$ & & \\
\hline Internal Networks & $\begin{array}{l}0.065^{* * *} \\
(0.007)\end{array}$ & & & $\begin{array}{c}0.060^{* * *} \\
(0.007)\end{array}$ & & \\
\hline External Networks & $\begin{array}{l}0.022^{* * *} \\
(0.006)\end{array}$ & & & $\begin{array}{l}0.018^{* * *} \\
(0.006)\end{array}$ & & \\
\hline Partner cooperation & $\begin{array}{c}0.095^{* * *} \\
(0.011)\end{array}$ & & & $\begin{array}{c}0.100^{* * *} \\
(0.011)\end{array}$ & & \\
\hline
\end{tabular}


Table 4.

Results of the Multi-level Zero Inflated Poisson ZIP Model (Continued)

\begin{tabular}{|c|c|c|c|c|c|c|}
\hline Variables & $\begin{array}{c}\text { Poisson } \\
\text { without } \\
\mathrm{OEV}\end{array}$ & ISIC & $\mathrm{CD}$ & $\begin{array}{c}\text { Poisson } \\
\text { with } \\
\text { OEV }\end{array}$ & ISIC & $\mathrm{CD}$ \\
\hline $\begin{array}{l}\text { Level of education: Bachelor. } \\
\text { Master and PhD }\end{array}$ & $\begin{array}{l}0.132^{* * *} \\
(0.005)\end{array}$ & & & $\begin{array}{l}0.128^{* * *} \\
(0.005)\end{array}$ & & \\
\hline $\begin{array}{l}\text { Level of education: associate } \\
\text { degree }\end{array}$ & $\begin{array}{l}0.022^{* * *} \\
(0.006)\end{array}$ & & & $\begin{array}{c}0.031^{* * *} \\
(0.006)\end{array}$ & & \\
\hline $\begin{array}{l}\text { Level of education: Bachelor. } \\
\text { Master and PhD involve in } \\
\text { R\&D }\end{array}$ & $\begin{array}{c}0.006 \\
(0.004)\end{array}$ & & & $\begin{array}{l}0.007^{*} \\
(0.004)\end{array}$ & & \\
\hline $\begin{array}{l}\text { Level of education: associate } \\
\text { degree involve in R\&D }\end{array}$ & $\begin{array}{c}-0.078^{* * *} \\
(0.005)\end{array}$ & & & $\begin{array}{c}-0.080^{* * *} \\
(0.005)\end{array}$ & & \\
\hline $\begin{array}{l}\text { Intellectual property and } \\
\text { patents }\end{array}$ & $\begin{array}{l}0.014^{* * *} \\
(0.003)\end{array}$ & & & $\begin{array}{l}0.029^{* * *} \\
(0.003)\end{array}$ & & \\
\hline Knowledge intensity: High & $\begin{array}{l}0.325^{* * *} \\
(0.046)\end{array}$ & & & $\begin{array}{l}0.425^{* * *} \\
(0.066)\end{array}$ & & \\
\hline Intensity of knowledge: Low & $\begin{array}{l}-0.009 \\
(0.230)\end{array}$ & & & $\begin{array}{l}-0.012 \\
(0.232)\end{array}$ & & \\
\hline Intensity of R\&D & $\begin{array}{l}0.227^{* *} \\
(0.106)\end{array}$ & & & $\begin{array}{l}0.254^{* *} \\
(0.117)\end{array}$ & & \\
\hline Sectors with foreign capital & & & & $\begin{array}{l}-0.107 \\
(0.103)\end{array}$ & & \\
\hline $\begin{array}{l}\text { Commercial Opening Index } \\
\text { of the sector }\end{array}$ & & & & $\begin{array}{l}-0.062 \\
(0.068)\end{array}$ & & \\
\hline $\begin{array}{l}\text { Unemployment rate by } \\
\text { department }\end{array}$ & $\begin{array}{l}0.514^{* * *} \\
(0.084)\end{array}$ & & & $\begin{array}{c}0.700^{* * *} \\
(0.108)\end{array}$ & & \\
\hline Coverage in higher education & $\begin{array}{l}0.218^{* * *} \\
(0.064)\end{array}$ & & & $\begin{array}{l}0.348^{* * *} \\
(0.069)\end{array}$ & & \\
\hline $\begin{array}{l}\text { Commercial opening index of } \\
\text { the region }\end{array}$ & & & & $\begin{array}{l}0.222^{* * *} \\
(0.062)\end{array}$ & & \\
\hline $\begin{array}{l}\text { National investment by } \\
\text { region in R\&D }\end{array}$ & $\begin{array}{l}0.738^{* * *} \\
(0.067)\end{array}$ & & & $\begin{array}{l}0.742^{* * *} \\
(0.065)\end{array}$ & & \\
\hline Distance to the Capital & $\begin{array}{l}-0.282^{* * * *} \\
(0.050)\end{array}$ & & & $\begin{array}{c}-0.284^{* * *} \\
(0.044)\end{array}$ & & \\
\hline Research groups & $\begin{array}{c}-0.912^{* * *} \\
(0.092)\end{array}$ & & & $\begin{array}{l}-0.978^{* * *} \\
(0.090)\end{array}$ & & \\
\hline Log-Likelihood Empty Model & & $-61,256.359$ & & & $-61,2563.59$ & \\
\hline Log-Likelihood Full Model & & $-57,301.352$ & & & $-57,148.843$ & \\
\hline Pseudo R2 & & $6.456 \%$ & & & $6.705 \%$ & \\
\hline
\end{tabular}

\section{EMPIRICAL FINDINGS}

Two scenarios have been used to test both hypotheses. In the first scenario, the economy is closed and therefore the model includes ten variables at the firm level, three at the sectoral level, and five at the regional level. In the second scenario, there is an open economy and therefore the model includes the same variables as the first model plus the OEV variables: three OEV at the firm level, two at the sectoral level, and one at the regional level were added to the model. 
After running the first model under the assumption of a closed economy, we can identify in Table 4 that nine out of the ten firm-level variables are significant. We find that the percentage of national private capital invested in R\&D and personnel with an associate degree that involves R\&D are negatively associated with innovative productivity of firms. In addition, at the second level, two out of three variables are significant. The sectors with high R\&D and knowledge intensities have a positive influence on the innovative performance of industrial manufacturing firms. Previous studies, such as Savrul and Incekara (2015) and Zawislak et al. (2018), have also confirmed that sectors with high R\&D and knowledge intensities have a positive effect on innovation. Finally, at the third level, all five variables are significant. Two of these variables, viz., distance to the capital city and research groups, have negative effects on innovation. First, Concilio et al. (2019), Florida et al. (2017), and Rammer et al. (2020) have explained that capital cities are hubs of science and technology. Hence, considering the results, companies that are more distant from capital cities tend to innovate less. Second, in Colombia, R\&D activities are supported by research groups and universities. The latest report of the Colombian Ministry of Science, Technology, and Innovation (2020) shows that, on average, only $5 \%$ of the research groups are involved in high intensive technology sectors, while $37 \%$ of the research groups are involved in social sciences and education. Therefore, the interpretation of the negative effect of research groups on innovation performance of manufacturing firms reflects, to some extent, the lack of technology-oriented research groups.

After running the second model with the assumption of the open economy, firm-level OEV in Table 4 is significant. However, from the multilevel perspective, some variables have unexpected coefficient signs. For example, companies with foreign capital have a lower total count of innovation by $\exp (-0.180)=0.835$ times the expected number of companies with no foreign capital. We expected that companies with more foreign capital would have a higher innovation count compared with other firms. These interpretations can change according to the country's FDI agenda. According to the Colombian Central Bank, during the period 2007-2008, the mining and oil extraction sector captured almost $50 \%$ of the total FDI, while the manufacturing industry only attracted, on average, $16.5 \%$ of the total FDI during the same period. Even though firms demand FDI, this investment does not go to the innovative sectors of the manufacturing industry, thereby hurting the innovation count. Blanco-Estévez (2015) concluded that Latin American firms invest only 0.60 US dollars per 100.000 US dollars in income in R\&D, while emerging countries in Asia invest 17 US dollars.

Additionally, if the percentage of private foreign capital invested in $R \mathcal{E} D$ was to increase by one percent, the expected number of innovations would increase by a factor of $\exp (0.0134)=1.0134$. According to Morero (2017), in developing countries, local firms are not getting enough R\&D investment from the local private sector. Hence, local firms will demand foreign R\&D investment. Holding the rest of the variables constant, if the firm increases its proportion of foreign capital by one percent then the count of innovations will increase by a factor of $\exp (0.0283)=1.028$.

The Schumpeterian hypothesis of size (Schumpeter, 1934; 1943) is proven right in both scenarios. Control variables, such as networks, partner cooperation, patents, and intellectual property rights, maintain a significant and positive relationship, 
complying with previous studies, such as Baker et al. (2017), Balachandran and Hernandez (2018), Galaso and Kovárík (2018).

In terms of education, at the firm level, the model includes four variables. While holding the rest of the variables constant, if a firm hires one additional employee with a bachelor, master, and Ph.D. degree, it will increase its innovations by a factor of $\exp (0.132)=1.141$ and $\exp (0.128)=1.136$ under closed and open economy, respectively. If a firm hires one additional employee with an associate degree, it will increase innovations by a factor of $\exp (0.0221)=1.022$ and $\exp (0.0319)=1.032$ under closed and open economy, respectively. Furthermore, firms that hire one more employee with a bachelor, master, and Ph.D. degree in the R\&D department under the open economy scenario will increase their innovation by a factor of $\exp (0.00778)=1.007$. Conversely, companies that hire one more employee with an associate degree in the R\&D department will decrease their innovation by a factor of $\exp (-0.0789)=0.924$ and $\exp (-0.0808)=0.923$ under the closed and open economy scenarios, respectively. If we look closer at the EDIT 2007-2008 bulletin, only $0.1 \%$ of the personnel employed in the industry reached doctoral level, $0.4 \%$ had a master degree, $12 \%$ had bachelor degree, and 9.1\% had an associate degree; not to mention the $31,4 \%$ of the companies that could not access skilled personnel.

At the sectoral level, only two variables are significant. Sectors with high knowledge intensity have positive effects in both scenarios (i.e., closed and open economies). The intensity of R\&D also generates a positive effect on the innovation counts. Nevertheless, the model does not show enough evidence to determine the impact of the OEV in the sectors.

At the regional level, all variables are significant. Control variables, such as distance to the capital city and the number of active research groups have a negative impact on innovation, by decreasing the propensity to innovate. The unemployment rate, coverage in higher education, the commercial opening index, and the national investment in R\&D have a positive relationship with innovation.

Education plays an important role in the process of innovation. Keeping the rest of the variables unchanged in the model, if the coverage of higher education in the region increases by one percent, the firms will increase the count of innovation by a factor of $\exp (0.218)=1.243$ and $\exp (0.348)=1.416$ under closed and open economy, respectively.

When the commercial opening index at the regional level increases by one percent, the firms will increase their innovation count by a factor of $\exp (0.222)=1.248$. Even though the commercial opening index of the region has a positive effect on innovation, it is important to mention that, in Colombia, high technology represented $19.8 \%$ of total imports, while medium technology reaches $35.7 \%$ of total imports during the period 2007-2008. On the other hand, DANE showed that high technology exports in Colombia represented only $2.3 \%$ of the total exports, which is low compared with the Latin America average of $11 \%$. The Colombian economy is highly dependent. on coal and oil, as commodities represent almost half of the total exports.

Table A.2 in the appendix is used as robustness checks and shows the results for the three types of innovations. As seen, OEV still has a significant relationship with innovation performance. Our firm-level variables of interest hold significance even after controlling for OEV variables (see Table A.2). We have also run the logit 
estimation for robustness and reported the estimates in Table A.3. Looking at these robustness checks in Table A.2 and Table A.3, we conclude that our findings are rather robust to alternative modeling strategies.

\section{CONCLUSIONS}

This study examines the roles of education and open economy variables (or OEV) in the innovative performance of Colombian manufacturing firms. Consistent with our expectations, we find that education is fundamental to innovation performance and development. The econometric model at the firm level shows a positive relationship between innovation and higher education, implying that it is important to strengthen the link between universities and industry. Promoting university-industry collaboration will improve technological capabilities, the acquisition and the adoption of new knowledge and technology, R\&D activities, and the development of new products. All these advantages can be obtained, if governments apply the best policy agenda that stimulates university-industry linkage.

Even though there is a positive relationship between coverage in higher education and innovation performance of firms, the quality of education and the enrolment rate in Colombia needs to catch up with OECD country members. Despite the lack of evidence at the sectoral level, our model with OEV variables shows that these variables are positively related to innovation count at both the regional and firm levels. This confirms that trade and FDI have a positive impact on innovation through knowledge and technology transfer to local firms.

Furthermore, our findings are supportive of our hypothesis that the innovative performance of firms is significantly related to open economy variables. Even though there is a significant relationship between innovation and the open economy variables, the interpretations may bring different insights. According to the results, we can conclude that even though firms have a percentage of FDI, it does not necessarily mean that FDI positively influences innovation unless firms allocate a fraction of it to R\&D activities.

At the regional level, we conclude that foreign trade has a positive impact on the innovation performance of firms. This positive impact is related to technology transfer. Despite the positive impact of foreign trade on innovation, Colombia must strengthen its technological capabilities to boost high technology exports.

After analyzing the education and foreign trade variables, we conclude that Colombia has a fragmented innovation system with a weak institutional structure, and low interaction between policymakers, industry, universities, research centers, and other components and building blocks of the system. Given the complexity of the behavior of innovation systems in emerging economies, Colombia needs to align its economic development agenda by promoting science, technology, and innovation policies without leaving out the environmental factors, the population's welfare, and development. Following the same research line of innovation systems in emerging economies, different research questions for future studies are also arising. For example, how can we measure university-industry cooperation in Colombia? How can we evaluate the technological capabilities of the Colombian system? What is the performance of innovation in other sectors such as agriculture and services? What are the impacts of digitalization on innovation performance? 


\section{REFERENCES}

Aguilera, A., \& Ramos-Barrera, M. G. (2016). Technological Unemployment: An Approximation to the Latin American Case. AD-Minister, 29, 59-78. https://doi.org/10.17230/ad-minister.29.3

Albats, E., Bogers, M., \& Podmetina, D. (2020). Companies' Human Capital for University Partnerships: A Micro-foundational Perspective. Technological Forecasting and Social Change, 157. https://doi.org/10.1016/j.techfore.2020.120085

Ardito, L., Petruzzelli, A. M., \& Albino, V. (2015). From Technological Inventions to New Products: A Systematic Review and Research Agenda of the Main Enabling Factors. 12, 113-147. https://doi.org/10.1111/emre.12047

Ascani, A., Crescenzi, R., \& Iammarino, S. (2012). Regional Economic Development : A Review. In SEARCH Working Paper (Vol. 1, Issue 03). http://www.ub.edu/ searchproject/wp-content/uploads/2012/02/WP-1.3.pdf

Baker, D., Jayadev, A., \& Stiglitz, J. (2017). Innovation, Intellectual Property, and Development: A Better Set of Approaches for the $21^{\text {st }}$ Century. In AccessIBSA: Innovation and Access to Medicines in India, Brazil, and South Africa (Issue July).

Balachandran, S., \& Hernandez, E. (2018). Networks and Innovation: Accounting for Structural and Institutional Sources of Recombination in Brokerage Triads. Organization Science, 29, 80-99. https://doi.org/10.1287/orsc.2017.1165

Barrios-Aguirre, F. (2013). El Ambiente Regional Y Empresarial En El Desempeño Innovador De Las Firmas Manufactureras Colombianas: ¿Quien Es Mas Importante? Conferência InternacionalLALICS2013. http://mail.redesist.ie.ufrj. br/lalics/papers/52_El_ambiente_regional_y_empresarial_en_el_desempeno_ innovador_de_las_firmas_manufactureras_colombianas_quien_es_mas_ importante.pdf

Baumann, J., \& Kritikos, A. S. (2016). The Link between R\&D, Innovation, and Productivity: Are Micro Firms Different? Research Policy, 45, 1263-1274. https://doi.org/10.1016/j.respol.2016.03.008

Bernard, A. B., and Bradford Jensen, J. (1999). Exceptional Exporter Performance: Cause, Effect, or Both? Journal of International Economics, 47, 1-25. https://ideas. repec.org/a/eee/inecon/v47y1999i1p1-25.html

Blanco-Estévez, A. (2015). The Latin American Foreign Investment Boom: Recent Trends and the Evolution of Multilatinas* The Reconfiguration of the Global Economy and the Emergence of Multilatinas. https://application-production.cdn.ranenetwork. com/blog/wp-content/uploads/2016/02/08044531/Blanco_Multilatinas_ English_final_0.pdf

Bogliacino, F., \& Pianta, M. (2016). The Pavitt Taxonomy Revisited : Patterns of Innovation in Manufacturing and Services. Economia Politica, 33, 153-180. https://doi.org/10.1007/s40888-016-0035-1

Cohen, W. M., \& Klepper, S. (1996). A Reprise of Size and R and D. Economic Journal, 106, 925-951. https://doi.org/10.2307/2235365

Cohen, W. M., \& Levin, R. C. (1989). Chapter 18 Empirical Studies of Innovation and Market Structure. In R. Schmalensee and R. Willig (Eds.), Handbook of Industrial Organization (Vol. 2, p. 1057). Elsevier. https://doi.org/10.1016/S1573-448X(89)02006-6

Concilio, G., Li, C., Rausell, P., \& Tosoni, I. (2019). Cities as Enablers of Innovation. In I. Tosoni and G. Concilio (Eds.), Innovation Capacity and the City (pp. 43-60). Springer Verlag. https://doi.org/10.1007/978-3-030-00123-0_3 
De Marchi, V., \& Grandinetti, R. (2017). Regional Innovation Systems or Innovative Regions? Evidence from Italy. Tijdschrift Voor Economische En Sociale Geografie, 108, 234-249. https://doi.org/10.1111/tesg.12217

Fagerberg, J., Srholec, M., \& Verspagen, B. (2009). Working Paper Series Innovation and Economic Development, 31, 1-74.

Feldman, M. P., \& Audretsch, D. B. (1999). Innovation in cities: Cities: Sciencebased Diversity, Specialization and Localized Competition. European Economic Review, 43, 409-429. https://doi.org/10.1016/S0014-2921(98)00047-6

Florida, R., Adler, P., \& Mellander, C. (2017). The City as Innovation Machine. Regional Studies, 51, 86-96. https://doi.org/10.1080/00343404.2016.1255324

Freeman, C. (1982). The Economics of Industrial Innovation. 2nd Edition, Francis Pinter, London.

Frey, C. B., \& Osborne, M. A. (2017). The future of employment: How Susceptible are Jobs to Computerisation? Technological Forecasting and Social Change, 114, 254-280. https://doi.org/10.1016/j.techfore.2016.08.019

Galaso, P., \& Kovářík, J. (2018). Munich Personal RePEc Archive Collaboration Networks and Innovation: How to Define Network Boundaries. Munich Personal RePEc Archive, 85108, 1-33.

Gelman, A., \& Hill, J. (2006). Data Analysis Using Regression and Multilevel/Hierarchical Models. In Data Analysis Using Regression and Multilevel/Hierarchical Models. Cambridge University Press. https://doi.org/10.1017/cbo9780511790942

Gera, S., \& Masse, P. (1996). Employment Performance in the Knowledge-based Economy. In Gouvernement du Canada - Industrial Organization. Gouvernement du Canada - Industry Canada. https://www.ic.gc.ca/eic/site/eas-aes.nsf/vwapj/ wp14e.pdf/\$file/wp14e.pdf

Guevara-Rosero, G. C. (2020). Trade, Innovation and Agglomeration. A Case Study for Colombia. Estudios Gerenciales, 36, 156-166. https://doi.org/10.18046/j.estger.2020.155.3383

Guillard, C., \& Salazar, M. (2017). La Experiencia en Encuestas de Innovación de Algunos Países Latinoamericanos. El Estado de La Ciencia 2017. RICyT/ OEI. http://www.ricyt.org/files/Estado de la Ciencia 2017/E_2017_2_3_La_ Experiencia_en_Encuestas_de_Innovacion.pdf

Gupta, A. K., Tesluk, P. E., \& Taylor, M. S. (2007). Innovation at and Across Multiple Levels of Analysis. Organization Science, 18, 885-897. https://doi.org/10.1287/orsc.1070.0337

Hadhri, W., Arvanitis, R., \& M'Henni, H. (2016). Determinants of Innovation Activities in Small and Open Economies: The Lebanese Business Sector. Journal of Innovation Economics, 21, 77-107. https://doi.org/10.3917/jie.021.0077

Hox, J. J., Moerbeek, M., \& Schoot, R. van de. (2017). Multilevel Analysis: Techniques and Applications, Third Edition (Vol. 7, Issue 2). Routledge. https://www. routledge.com/Multilevel-Analysis-Techniques-and-Applications-ThirdEdition/Hox-Moerbeek-Schoot/p/book/9781138121362

Hur, K., Hedeker, D., Henderson, W., Khuri, S., \& Daley, J. (2002). Modeling Clustered Count Data with Excess Zeros in Health Care Outcomes Research. Health Services and Outcomes Research Methodology, 3, 5-20. https://doi.org/10.1023/A:1021594923546 
ICTSD. (2016). Trade and Innovation: Policy Options for a New Innovation Landscape. International Centre for Trade and Sustainable Development. https://e15initiative.org/wp-content/uploads/2015/09/E15_ICTSD_Trade_ Innovation_report_2016_1002.pdf

Joseph, K. J. (2009). Sectoral Innovation Systems in Developing Countries: The Case of ICT in India. In B.-Å. Lundvall, K. J. Joseph, C. Chaminade, and J. Vang (Eds.), Handbook of Innovation Systems and Developing Countries, (pp. 183-213). Edward Elgar Publishing. https://econpapers.repec.org/RePEc:elg:eechap:12943_7

Juhro, S. M., Narayan, P. K., Iyke, B. N., \& Trisnanto, B. (2020). Is there a Role for Islamic Finance and R\&D in Endogenous Growth Models in the Case of Indonesia? Pacific-Basin Finance Journal, 62, 101297. https://doi.org/10.1016/j.pacfin.2020.101297

Keller, W. (2010). International Trade, Foreign Direct Investment, and Technology Spillovers. In Handbook of the Economics of Innovation Volume 2 (1st ed., Vol. 2). Elsevier B.V. https://doi.org/10.1016/S0169-7218(10)02003-4

Kuhlmann, S., \& Ordóñez-Matamoros, G. (2017). Introduction : Governance of Innovation in Emerging Countries: Understanding Failures and Exploring Options. In S. Kuhlmann and G. Ordóñez-Matamoros (Eds.), Research Handbook on Innovation Governance for Emerging Economies: Towards Better Models (pp. 1-34). Edward Elgar Publishing.

Lambert, D. (1992). Zero-Inflated Poisson Regression, with an Application to Defects in Manufacturing. Technometrics, 34, 1. https://doi.org/10.2307/1269547

Laurin, F., \& St-Pierre, J. (2011). The Internationalisation of SMEs and the Relationships between Imports and Exports. Research Institute for SMES Université Du Québec à Trois-Rivières, January, 1-21. https://www.kmu-hsg.ch/ rencontres2012/resources/Topic_A/Rencontres_2012_Topic_A_Laurin.pdf

Lee, A. H., Wang, K., Scott, J. A., Yau, K. K. W., \& McLachlan, G. J. (2006). Multilevel zero-inflated Poisson Regression Modelling of Correlated Count Data with Excess Zeros. Statistical Methods in Medical Research, 15, 47-61. https://doi.org/10.1191/0962280206sm429oa

Lefebvre, E., \& Lefebvre, L.-A. (2002). Innovative Capabilities as Determinants of Export Performance and Behaviour: A Longitudinal Study of Manufacturing SMEs. In A. Kleinknecht and P. Mohnen (Eds.), Innovation and Firm Performance (pp. 281-309). Palgrave Macmillan UK. https://doi.org/10.1057/9780230595880_12

Long, J. S. (1997). Regression Models for Categorical and Limited Dependent Variables. In SAGE Publications. https://doi.org/10.2307/3006005

Lundvall, B.- $\AA$. (1985). Product Innovation and User-Producer Interaction. Aalborg University Press, Aalborg.

Lundvall, B.-A. (2015). The Origins of the National Innovation System Concept and its Usefulness in the Era of the Globalizing Economy. 13th Globelics Conference, 2015, May, 1-29.

Lundvall, B.-Å., Vang, J., \& Chaminade, C. (2009). Epilogue: Which Way Now? In Handbook of Innovation Systems and Developing Countries: Building Domestic Capabilities in a Global Setting (pp. 380-386).

MacGregor-Pelikánová, R. (2019). R\&D Expenditure and Innovation in the EU and Selected Member States. Journal of Entrepreneurship, Management and Innovation, 15, 13-34. https://doi.org/10.7341/20191511 
Malerba, F. (2002). Sectoral Systems of Innovation and Production. Research Policy, $31,247-264$.

Malerba, F. (2005). Sectoral Systems of Innovation: A Framework for Linking Innovation to the Knowledge Base, Structure and Dynamics of Sectors. Economics of Innovation and New Technology, 14, 63-82. https://doi.org/10.1080/1043859042000228688

Manyika, J., Chui, M., \& Joshi, R. (2018). Modeling the Global Economic Impact of AI I McKinsey. McKinsey, September. https://www.mckinsey.com/featuredinsights/artificial-intelligence/notes-from-the-ai-frontier-modeling-theimpact-of-ai-on-the-world-economy

Marotta, D., Mark, M., Blom, A., \& Thorn, K. (2007). Human Capital and UniversityIndustry Linkages' Role in Fostering Firm Innovation: An Empirical Study of Chile and Colombia. The World Bank. https://doi.org/10.1596/1813-9450-4443

Ministry of Science Technology and Innovation. (2020). Colombia Hacia Una Sociedad Del Conocimiento. https://minciencias.gov.co/sites/default/files/upload/ paginas/ebook-_colombia_hacia_una_sociedad_del_conocimiento.pdf

Morero, H. A. (2017). The Role of Public Policies in Promoting Innovation and Innovation Complementarities in Developing Countries: the Case of the Argentinian software Industry. In A. Tsvetkova, J. Schmutzler, M. Suarez, and A. Faggian (Eds.), Innovation in Developing and Transition Countries New Horizons in Regional Science series (pp. 109-128). Edward Elgar Publishing. https://econpapers.repec.org/RePEc:elg:eechap:17239_6

OECD.(2012).InnovationforDevelopment.InOECDDirectoratefor Science, Technology and Industry. https://doi.org/10.1093/acprof:oso/9780199671656.003.0036

OECD. (2014). OECD Review of Innovation Policy: Colombia Overall Assessment and Recommendations. https://www.oecd.org/sti/inno/colombia-innovationreview-assessment-and-recommendations.pdf

Padilla-Pérez, R., Vang, J., \& Chaminade, C. (2009). Regional Innovation Systems in Developing Countries: Integrating Micro and Meso-level Capabilities. In B.-Å. Lundvall, K. J. Joseph, C. Chaminade, and J. Vang (Eds.), Handbook of Innovation Systems and Developing Countries Building Domestic Capabilities in a Global Setting (pp. 140-182). Edward Elgar Publishing. https://ideas.repec. org/h/elg/eechap/12943_6.html

Paunov, C., Guellec, D., El-Mallakh, N., Planes-Satorra, S., \& Nüse, L. (2019). On the Concentration of Innovation in Top Cities in the Digital Age. In OECD Science, Technology And Innovation Policy Papers: Vol. No. 85 (Issue December). https://doi.org/10.1787/f184732a-en

Powell, W. W., \& Grodal, S. (2006). Networks of Innovators. In J. Fagerberg and D. C. Mowery (Eds.), The Oxford Handbook of Innovation (pp. 56-85). Oxford University Press. https://doi.org/10.1093/oxfordhb/9780199286805.003.0003

Prodan, I., Prodan, \& Igor. (2005). Influence of Research and Development Expenditures on Number of Patent Aplications: Selected Case Studies in OECD countries and Central Europe, 1981-2001. Applied Econometrics and International Development, 5, 5-22. https://econpapers.repec.org/RePEc:eaa:aeinde:v:5:y:200 5:i:4_1

Rammer, C., Kinne, J., \& Blind, K. (2020). Knowledge Proximity and Firm Innovation: A Microgeographic Analysis for Berlin. Urban Studies, 57, 9961014. https://doi.org/10.1177/0042098018820241 
RICYT. (2018). Ibero- American Network for Science and Technology Indicators. http:// app.ricyt.org/ui/v3/comparative.html?indicator=VADORASxMANU\&start_ year=2009\&end_year=2018

Romijn, H., \& Albaladejo, M. (2002). Determinants of Innovation Capability in Small Electronics and Software Firms in Southeast England. Research Policy, 31, 1053-1067. https://doi.org/10.1016/S0048-7333(01)00176-7

Savrul, M., \& Incekara, A. (2015). The Effect of R\&D Intensity on Innovation Performance: A Country Level Evaluation. Procedia - Social and Behavioral Sciences, 210, 388-396. https://doi.org/10.1016/j.sbspro.2015.11.386

Schumpeter, J. A. (1934). The Theory of Economic Development: An Inquiry into Profits, Capital, Credit, Interest, and the Business Cycle. University of Illinois . https:// papers.ssrn.com/abstract=1496199

Schumpeter, J. A. (1943). Capitalism, Socialism and Democracy. George Allen and Unwin. https://eet.pixel-online.org/files/etranslation/original/Schumpeter, Capitalism, Socialism and Democracy.pdf

Srholec, M. (2011). A Multilevel Analysis of Innovation in Developing Countries. CERGE-EI. https://www.cerge-ei.cz/pdf/wp/Wp432.pdf

Srholec, M. (2015). Understanding the Diversity of Cooperation on Innovation Across Countries: Multilevel Evidence from Europe. Economics of Innovation and New Technology, 24, 159-182. https://doi.org/10.1080/10438599.2014.897864

UNCTAD. (2014). Science, Technology and Innovation for the Post-2015 Development Agenda Report of the Secretary-general Economic and Social Council. http://blog. euromonitor.com/2012/03/special-report-income-

Urraca-Ruiz, A. (2000). Patrones Sectoriales De Cambio Técnico En La Industria Española. Economía Industrial, 332, 99-108.

Vélez-Rolón, A. M., Méndez-Pinzón, M., \& Acevedo, O. L. (2020). Open Innovation Community for University-industry Knowledge Transfer: A Colombian Case. Journal of Open Innovation: Technology, Market, and Complexity, 6, 1-17. https://doi.org/10.3390/joitmc6040181

Vogel, A., \& Wagner, J. (2010). Higher Productivity in Importing German Manufacturing Firms: Self-selection, Learning from Importing, or Both? Review of World Economics, 145, 641-665. https://doi.org/10.1007/s10290-009-0031-4

Wang, J., Xie, H., \& Fisher, J. H. (2011). Multilevel Models: Applications using SAS®. In Multilevel Models: Applications using SAS. Walter de Gruyter. https://doi.org/10.1515/9783110267709

Winkelmann, R. (2008). Econometric Analysis of Count Data. In Econometric Analysis of Count Data. Springer Berlin Heidelberg. https://doi.org/10.1007/978-3-540-78389-3

Wooldridge, J. M. (2002). Econometric Analysis of Cross Section and Panel Data. In MIT press. https://doi.org/10.1515/humr.2003.021

Zawislak, P. A., Fracasso, E. M., \& Tello-Gamarra, J. (2018). Technological Intensity and Innovation Capability in Industrial Firms. Innovation and Management Review, 15, 189-207. https://doi.org/10.1108/inmr-04-2018-012

Zuluaga Jiménez, J. C., Sánchez Manchola, I. D., \& Barrios Aguirre, F. (2012). Ambiente Regional Y Desempeño Innovador De Las Firmas. Una Propuesta De Análisis Multinivel. Estudios Gerenciales, 28, 169-189. https://doi.org/10.18046/j.estger.2012.1484 


\section{APPENDIX}

Table A.1.

\section{Summary Statistics for Independent Variables}

This table reports the summary statistics for independent variables We refer to Table 3 for the description of the variables.

\begin{tabular}{|c|c|c|c|c|}
\hline Variables & Size & $\begin{array}{c}\text { Percentage of } \\
\text { National Private } \\
\text { Capital Invested in } \\
\text { R\&D }\end{array}$ & $\begin{array}{c}\text { Percentage of } \\
\text { Foreign Private } \\
\text { Capital Invested } \\
\text { in R\&D }\end{array}$ & Internal Networks \\
\hline Observations & 5,273 & 5,273 & 5,273 & 5,273 \\
\hline $\min$ & 1 & 0 & 0 & 0 \\
\hline $\max$ & 7,640 & 46,357 & 46,966 & 1 \\
\hline range & 7,639 & 46,357 & 46,966 & 1 \\
\hline sum & 598,001 & 1135151.630 & 411697.010 & 1553.048 \\
\hline median & 34 & 100 & 0 & 0 \\
\hline mean & 113.408 & 215.276 & 78.076 & 0.295 \\
\hline var & 84599.343 & 4710010.107 & 3189563.928 & 0.135 \\
\hline std.dev & 290.860 & 2170.256 & 1785.935 & 0.368 \\
\hline Variables & $\begin{array}{l}\text { External } \\
\text { Networks }\end{array}$ & Partner Cooperation & $\begin{array}{c}\text { Level of } \\
\text { Education: } \\
\text { Bachelor, Master } \\
\text { and PhD } \\
\end{array}$ & $\begin{array}{l}\text { Level of Education: } \\
\text { Association Degree }\end{array}$ \\
\hline Observations & 5,273 & 5,273 & 5,273 & 5,273 \\
\hline $\min$ & 0 & 0 & 0 & 0 \\
\hline $\max$ & 1 & 1 & 1 & 1 \\
\hline range & 1 & 1 & 1 & 1 \\
\hline sum & 854.95 & 1,090 & 610.24 & 427.75 \\
\hline median & 0 & 0 & 0.08 & 0.03 \\
\hline mean & 0.16 & 0.21 & 0.12 & 0.08 \\
\hline var & 0.06 & 0.16 & 0.02 & 0.02 \\
\hline std.dev & 0.25 & 0.40 & 0.12 & 0.14 \\
\hline Variables & $\begin{array}{l}\text { Level of } \\
\text { Education: } \\
\text { Bachelor, } \\
\text { Master, and } \\
\text { PhD involve } \\
\text { in R\&D }\end{array}$ & $\begin{array}{l}\text { Level of Education: } \\
\text { Association Degree } \\
\text { Involve in R\&D }\end{array}$ & $\begin{array}{l}\text { Intellectual } \\
\text { Property and } \\
\text { Patents }\end{array}$ & $\begin{array}{l}\text { Foreign R\&D } \\
\text { Financing }\end{array}$ \\
\hline Observations & 5,273 & 5,273 & 5,273 & 5,273 \\
\hline $\min$ & 0 & 0 & 0 & 0 \\
\hline $\max$ & 0.625 & 0.750 & 90 & 1 \\
\hline range & 0.625 & 0.750 & 90 & 1 \\
\hline sum & 71.207 & 26.907 & 1,123 & 12.304 \\
\hline median & 0 & 0 & 0 & 0 \\
\hline mean & 0.014 & 0.005 & 0.213 & 0 \\
\hline var & 0 & 0 & 6.231 & 0 \\
\hline std.dev & 0.042 & 0.027 & 2.496 & 0.037 \\
\hline
\end{tabular}


Table A.1.

Summary Statistics for Independent Variables (Continued)

\begin{tabular}{lcccc}
\hline Variables & $\begin{array}{c}\text { Intensity of } \\
\text { R\&D }\end{array}$ & $\begin{array}{c}\text { Sectors with } \\
\text { Foreign Capital }\end{array}$ & $\begin{array}{c}\text { Commercial } \\
\text { Opening Index of } \\
\text { the Sector }\end{array}$ & $\begin{array}{c}\text { Unemployment } \\
\text { Rate by } \\
\text { Department }\end{array}$ \\
\hline Observations & 5,273 & 5,273 & 5,273 & 5,273 \\
min & 0 & 0 & 0 & 0 \\
max & 1 & 1 & $811,479,188,148,951$ & 0.157 \\
range & 1 & 1 & $811,479,188,148,951$ & 0.157 \\
sum & 3795 & 384 & $3.27 \mathrm{E}+17$ & 578.016 \\
median & 0.76 & 0.07 & 0.375 & 0.104 \\
mean & 0.72 & 0.07 & $62,066,726,263,379$ & 0.110 \\
var & 0.04 & 0.00 & $3.49 \mathrm{E}+28$ & 0.000 \\
std.dev & 0.20 & 0.06 & $186,828,935,906,393$ & 0.010 \\
\hline Variables & in Higher & Distance to the & National & Commercial \\
& Education & Capital & Region in R\&D & Opening Index of \\
the Region
\end{tabular}




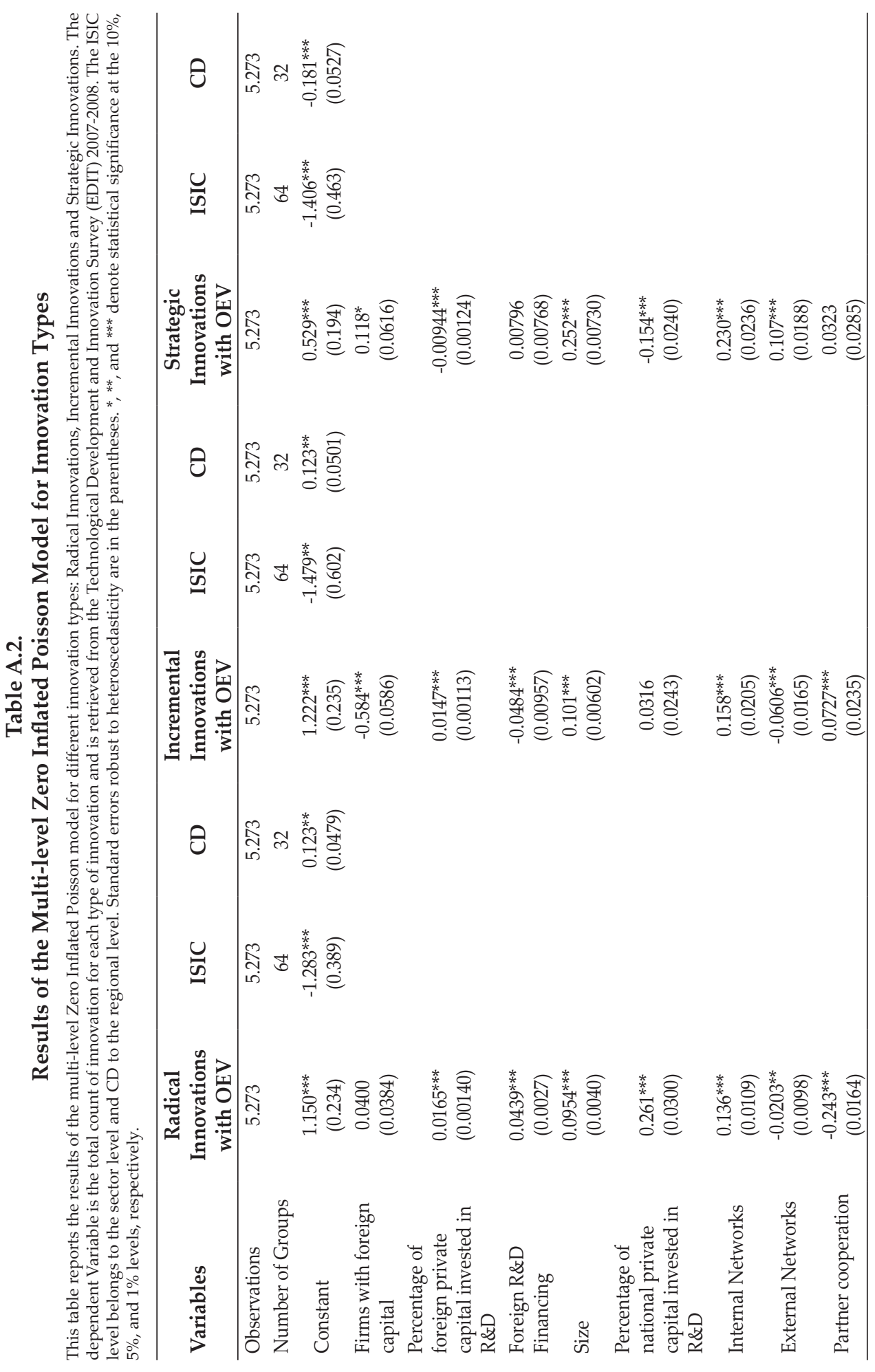




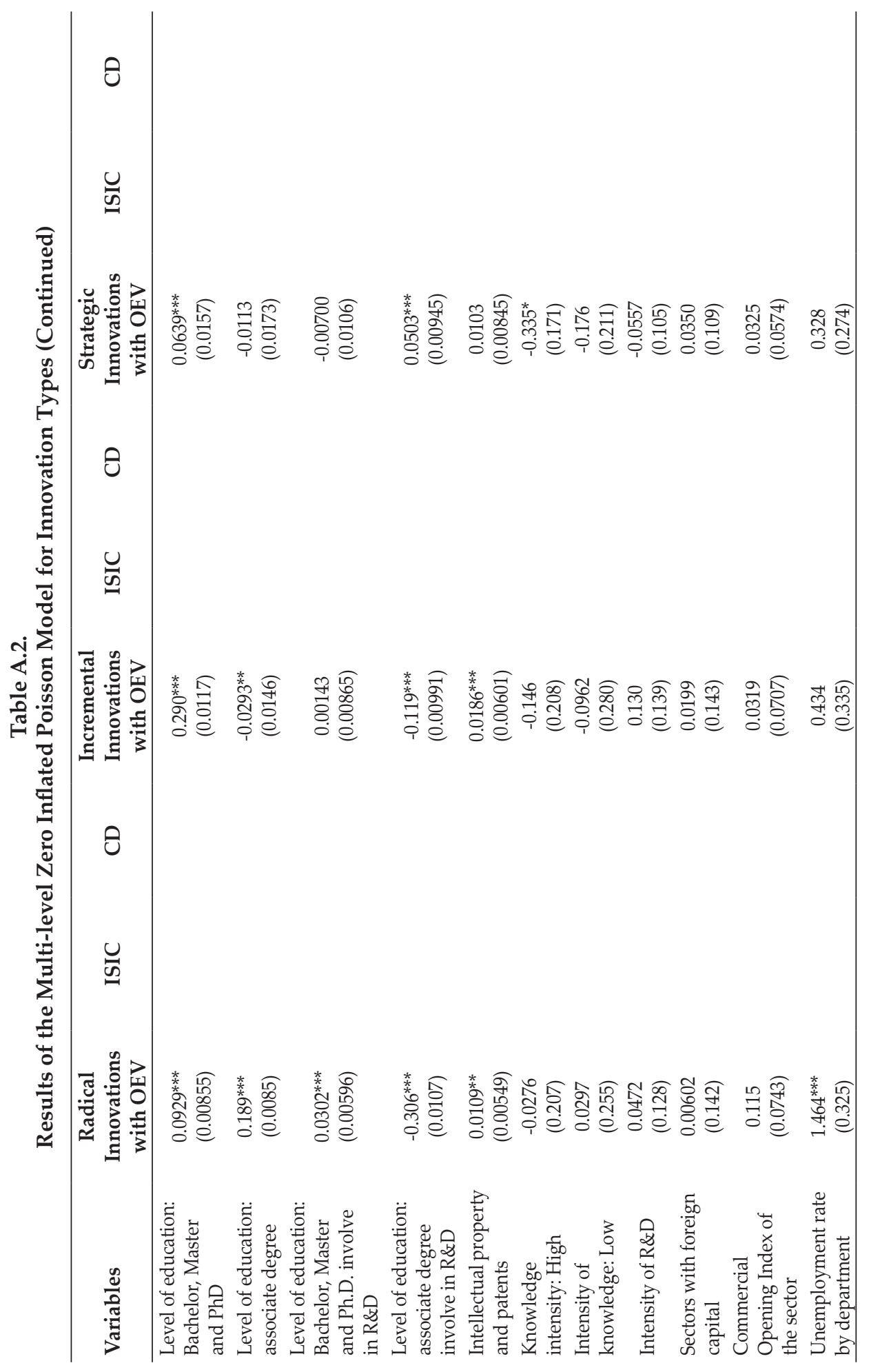




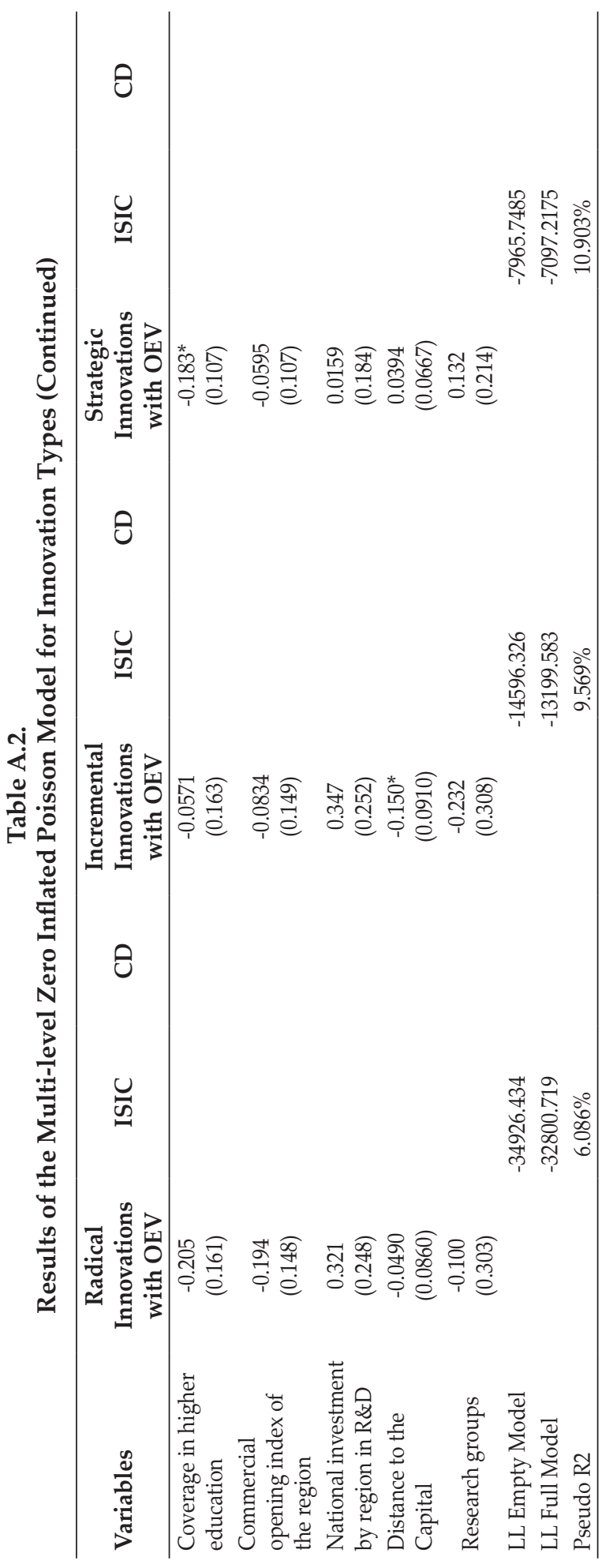


Table A.3.

\section{Results of the Logit model}

This table reports the results using the logit model with and without Open Economy Variables (OEV) for the full sample. Dependent Variable is total count of innovation based on the Technological Development and Innovation Survey (EDIT) 2007-2008. The ISIC level belongs to the sector level and CD to the regional level. Standard errors robust to heteroscedasticity are in the parentheses. ***, and ${ }^{* * *}$ denote statistical significance at the $10 \%, 5 \%$, and $1 \%$ levels, respectively.

\begin{tabular}{|c|c|c|c|c|c|c|}
\hline Variables & $\begin{array}{l}\text { Logit } \\
\text { without } \\
\text { OEV }\end{array}$ & ISIC & CD & $\begin{array}{l}\text { Logit } \\
\text { with } \\
\text { OEV }\end{array}$ & ISIC & $\mathrm{CD}$ \\
\hline Observations & 5,273 & 5,273 & 5,273 & 5,273 & 5,273 & 5,273 \\
\hline Number of Groups & & 64 & 32 & & 64 & 32 \\
\hline Constant & $\begin{array}{c}0.602^{* * *} \\
(0.208)\end{array}$ & $\begin{array}{l}-1.596^{* * *} \\
(0.283)\end{array}$ & $\begin{array}{l}-14.180 \\
(161.228)\end{array}$ & $\begin{array}{l}0.450^{*} \\
(0.259)\end{array}$ & $\begin{array}{l}-1.642^{* * *} \\
(0.297)\end{array}$ & $\begin{array}{l}-21.880 \\
(340.000)\end{array}$ \\
\hline Firms with foreign capital & & & & $\begin{array}{l}-0.338 \\
(0.267)\end{array}$ & & \\
\hline $\begin{array}{l}\text { Percentage of foreign } \\
\text { private capital invested } \\
\text { in R\&D }\end{array}$ & & & & $\begin{array}{l}-0,007 \\
(0.006)\end{array}$ & & \\
\hline Foreign R\&D Financing & & & & $\begin{array}{l}-0.127 \\
(0.092)\end{array}$ & & \\
\hline Size & $\begin{array}{l}-0.414^{* * *} \\
(0.067)\end{array}$ & & & $\begin{array}{c}-0.408^{* * *} \\
(0.067)\end{array}$ & & \\
\hline $\begin{array}{l}\text { Percentage of national } \\
\text { private capital invested } \\
\text { in R\&D }\end{array}$ & $\begin{array}{c}0,010 \\
(0.047)\end{array}$ & & & $\begin{array}{l}-0,069 \\
(0.118)\end{array}$ & & \\
\hline Internal Networks & $\begin{array}{c}-1.421^{* * *} \\
(0.0454)\end{array}$ & & & $\begin{array}{c}-1.422^{* * *} \\
(0.045)\end{array}$ & & \\
\hline External Networks & $\begin{array}{c}-0.698^{* * *} \\
(0.042)\end{array}$ & & & $\begin{array}{c}-0.694^{* * *} \\
(0.042)\end{array}$ & & \\
\hline Partner cooperation & $\begin{array}{c}-0.713^{* * *} \\
(0.118)\end{array}$ & & & $\begin{array}{c}-0.705^{* * *} \\
(0.118)\end{array}$ & & \\
\hline $\begin{array}{l}\text { Level of education: } \\
\text { Bachelor, Master and PhD }\end{array}$ & $\begin{array}{l}0.157^{* * *} \\
(0.053)\end{array}$ & & & $\begin{array}{l}0.155^{* * *} \\
(0.053)\end{array}$ & & \\
\hline $\begin{array}{l}\text { Level of education: } \\
\text { associate degree }\end{array}$ & $\begin{array}{l}0,0544 \\
(0.048)\end{array}$ & & & $\begin{array}{l}0,0534 \\
(0.048)\end{array}$ & & \\
\hline $\begin{array}{l}\text { Level of education: } \\
\text { Bachelor, Master and } \mathrm{PhD} \\
\text { involve in R\&D }\end{array}$ & $\begin{array}{c}-0.837^{* * *} \\
(0.0905)\end{array}$ & & & $\begin{array}{c}-0.834^{* * *} \\
(0.0906)\end{array}$ & & \\
\hline $\begin{array}{l}\text { Level of education: } \\
\text { associate degree involve } \\
\text { in R\&D }\end{array}$ & $\begin{array}{c}-0.170^{* * *} \\
(0.0537)\end{array}$ & & & $\begin{array}{l}-0.170^{* * *} \\
(0.0539)\end{array}$ & & \\
\hline $\begin{array}{l}\text { Intellectual property and } \\
\text { patents }\end{array}$ & $\begin{array}{l}-0.118 \\
(0.0874)\end{array}$ & & & $\begin{array}{l}-0.120 \\
(0.0869)\end{array}$ & & \\
\hline Knowledge intensity: High & $\begin{array}{l}-0,0463 \\
(0.144)\end{array}$ & & & $\begin{array}{l}-0,0116 \\
(0.176)\end{array}$ & & \\
\hline $\begin{array}{l}\text { Intensity of knowledge: } \\
\text { Low }\end{array}$ & $\begin{array}{c}0.103 \\
(0.184)\end{array}$ & & & $\begin{array}{l}0,0932 \\
(0.183)\end{array}$ & & \\
\hline Intensity of R\&D & $\begin{array}{l}-0,0252 \\
(0.102)\end{array}$ & & & $\begin{array}{l}-0,0206 \\
(0.107)\end{array}$ & & \\
\hline $\begin{array}{l}\text { Sectors with foreign } \\
\text { capital }\end{array}$ & & & & $\begin{array}{l}-0,045 \\
(0.163)\end{array}$ & & \\
\hline
\end{tabular}


Table A.3.

Results of the Logit model (Contiued)

\begin{tabular}{|c|c|c|c|c|c|c|}
\hline Variables & $\begin{array}{c}\text { Logit } \\
\text { without } \\
\text { OEV }\end{array}$ & ISIC & $\mathrm{CD}$ & $\begin{array}{l}\text { Logit } \\
\text { with } \\
\text { OEV }\end{array}$ & ISIC & CD \\
\hline $\begin{array}{l}\text { Commercial Opening } \\
\text { Index of the sector }\end{array}$ & & & & $\begin{array}{l}-0,019 \\
(0.051)\end{array}$ & & \\
\hline $\begin{array}{l}\text { Unemployment rate by } \\
\text { department }\end{array}$ & $\begin{array}{l}-0.251 \\
(0.307)\end{array}$ & & & $\begin{array}{l}-0.232 \\
(0.307)\end{array}$ & & \\
\hline $\begin{array}{l}\text { Coverage in higher } \\
\text { education }\end{array}$ & $\begin{array}{l}0.377^{* * *} \\
(0.115)\end{array}$ & & & $\begin{array}{l}0.508^{* * *} \\
(0.131)\end{array}$ & & \\
\hline $\begin{array}{l}\text { Commercial opening } \\
\text { index of the region }\end{array}$ & & & & $\begin{array}{l}0.295^{* *} \\
(0.136)\end{array}$ & & \\
\hline $\begin{array}{l}\text { National investment by } \\
\text { region in R\&D }\end{array}$ & $\begin{array}{c}0.142 \\
(0.153)\end{array}$ & & & $\begin{array}{c}0.186 \\
(0.155)\end{array}$ & & \\
\hline Distance to the Capital & $\begin{array}{l}-0,0952 \\
(0.0778)\end{array}$ & & & $\begin{array}{l}-0.155^{*} \\
(0.0823)\end{array}$ & & \\
\hline Research groups & $\begin{array}{l}-0.289 \\
(0.189)\end{array}$ & & & $\begin{array}{l}-0.421^{* *} \\
(0.198)\end{array}$ & & \\
\hline LL Empty Model & & -3515.3311 & & & -3515.3311 & \\
\hline LL Full Model & & -1718.6624 & & & -1713.5771 & \\
\hline Pseudo R2 & & $51.110 \%$ & & & $51.254 \%$ & \\
\hline
\end{tabular}


This page is intentionally left blank 